\title{
Identification of students' needs for multimedia development in craft and entrepreneurial topic: information technology-assisted learning
}

\author{
Mochamad Kamil Budiarto ${ }^{1^{*}}$ \\ ${ }^{1}$ Universitas Sebelas Maret, Indonesia \\ ${ }^{*}$ Corresponding author, ఏe-mail: kamiltp@student.uns.ac.id
}

\begin{abstract}
This study aims to identify the need for interactive multimedia development for learning crafts and entrepreneurship. Using a quantitative descriptive approach and data collection techniques is a needs analysis questionnaire which is then analyzed quantitatively using statistics to determine and the percentage of responses from the research sample used in this study. The subjects of this study consisted of 55 students of Class XI IPA of SMA N 1 Susukan, Cirebon. The results of the study report that the need for multimedia development for learning craft and entrepreneurship topic received positive responses from students and was supported by students who have the ability to operate computers in enough categorized, Schools also had been supported by computer laboratories. Given all this time, the module still dominates as a learning medium. This research can be the basis for educators to decide the need for interactive multimedia development by conducting a more in-depth needs analysis.
\end{abstract}

Keywords: Need analysis, instructional multimedia, ICT application, craft and entrepreneurship topic.

How to Cite: Budiarto, M. (2020). Identification of students' needs for multimedia development in craft and entrepreneurial topic: information technology-assisted learning. COUNS-EDU: The International Journal of Counseling and Education, 5(4). 153-162. DOI: http://dx.doi.org/10.23916 $/ 0020200525740$

This is an open access article distributed under the Creative Commons Attribution License, which permits unrestricted use, distribution, and reproduction in any medium, provided the original work is properly cited. (C2020 by author.

\section{Introduction}

The development of science and technology has entered into various areas of human life, for example in education. Technologies such as computers, smartphones, and the Internet have become an integral part of the learning process, although not all levels have been implemented, and in some cases, their use has not been optimalized. Technological development will make teachers able to offer innovations in the learning process (Yildirim \& Sensoy, 2018; Widodo, Huda, Dirgatama, \& Wirawan, 2020). In addition, The development of technology forces all components of the education system to be able to elaborate on the rapid development of science, information as a means to improve the quality of the learning process. so that teachers have the opportunity to take advantage of technology in the learning process in the classroom (Gan, Menkhoff, \& Smith, 2015; Jones, 2017).

Education in the 21st century is synonymous with the use of various scientific and technological innovations, one of which is the use of electronic learning media and the use of information and communication systems in education (Wihartanti \& Wibawa, 2017; Taseman \& Dahlan, 2018). Cause of that, Educational institutions around the world to make significant changes which can make they adapt the competency requirements of the Industrial Revolution 4.0 (RI 4.0), introducing technology to educators is one way that can be used by policy makers, so that classroom learning will be technology- 
based which leads to innovative learning (Hussin, 2018; Bayne, 2015), If this can be implemented, teachers will be more adaptive to learning conditions that are in accordance with current developments and technological advances. The application of ICT in learning will be able to help the world of education in the country to be able to create skilled human resources in the era of the industrial revolution 4.0 (Kali et al., 2015). By implementing education that is adapted to technological developments, teachers are expected to gain benefits such as computers and ICT skill, and then they would apply it in classroom to create a more interactive and modern learning activities.

Sudjana (2010) argues that teaching and learning activities are the implementation of the curriculum in each educational unit with the aim of helping and facilitating students in mastering a competency. The best learning process takes place when the teacher's role does not have much control over, because when teachers tend to dominate the implementation of learning, such as lecturing students, using one-way communication will actually cause students to be passive. (Hanafy, 2014). The academic results of students are basically influenced by various factors (Sutrisno \& Siswanto, 2016; Yuzarion, 2017), including students' factors, then the learning environment, teacher competency (Feng \& Sass, 2017), subject level difficulty, and the availability of learning resources owned by schools to support the learning process (Wanyama, 2017).

The way teacher chooses and applies the strategies, methods, and media of the learning process will affect the achievement of the competencies, just like was required in the twenty-first century (Rusdin, 2018). Knowing the materials, information and standards that have been developed for the learning process becomes students' initial knowledge, then choosing the appropriate learning resources for the needs is an important thing that teachers should be able to implement (Notanubun, 2019). Through the use of technology, teachers are expected to be able to improve the quality of education. The ICT-based learning system provides the dissemination of information that is more actual, faster, more effective, efficient and has the potential to support the implementation of learning (Hussin, 2018; Halili, 2019). Among the forms of integrated technology use in the learning process is web-based learning (Zhang, 2018; Huang, 2018), computer aided learning (Kapi, Kahbi, Osman, Ramli, \& Taib, 2017; Yue, 2017), and audiovisual-based learning (Asmara, 2015; Nicolaou, Matsiola, \& Kalliris, 2019).

practical and theoretical from the development and advancement of technology as described above, an education system is needed that must adapt to the use of ICT and relevant competencies in this century. So this will require changes in the implementation of the curriculum at the national level. Tania \& Fadiawati (2015) revealed that the ideal concept of the 2013 curriculum process standard was studentcentered, and contextual learning (Pramita et al., 2016), Learning media containing subject matter or information, supported by a comprehensive assessment system based on the needs of the competencies of this century, have the potential to be utilized.

Entrepreneurial competence is one of the competencies needed to be competitive in the era of the Industrial Revolution 4.0. Entrepreneurship education in general was a social process for shaping individual life skills through an integrated curriculum in schools (Suasana et al., 2020). In addition, competence in entrepreneurship was a skill that anyone can learn (Winardi, 2003), it made entrepreneurship include in the theme of the implementation of 2013 curriculum which aimed to change and develop student mind (Maresch et al., 2016). Entrepreneurial education that takes place in each educational unit is implemented in the form of craft and entrepreneurial materials. The topic of craft and entrepreneurship invites students learn skills in order to get opportunities in the context of developing entrepreneurial soft skills and selling products (Fardila et al., 2015).

Based on the results of the interview, it showed that the media often used by teachers is less attractive so students cannot understand the material presented. If students are not interested in learning, this will affect the learning outcomes that students have obtained. By monitoring activities in the learning process, some information was obtained that the teacher in carrying out learning in the classroom applies the task-centered learning, and the use of books or modules is controlled at the time of the learning process, and the materials provided have been linked to local capabilities (in topics Certain), during the two-hour learning (2 Jam Pelajaran), the teacher begins delivering materials from the teacher with books or media units provided by the government and blackboard, without using media presentations or another educational media, then students are given tasks at the end of the learning process the learner Enjoy the articles discussed. 
Unfortunately, Government printed books are not yet included in the interactive media category because they only provide static text and images (Daniel \& Woody, 2013). The learning process requires innovation to be able to create an educational environment that is integrated with technology while preserving information related to local potential or advantages as a tool to facilitate students in the learning process. Through an educational context that tends to be contextual, it is hoped that students will be able to interpret learning activities indirectly related to students' daily activities (Agustin, Wahyuni, \& Bachtiar, 2018; Sofyan, Anggereini, \& Saadiah, 2019).

The efforts that teachers can use as one of the innovations in the learning process was to create instructional media that can solve problems in the learning process in the classroom. Using computersupported learning media, such as multimedia, can make it easier for students to understand something abstract and clarify the presentation of information or educational materials (Sukiman, 2012) and improve the learning process and results (Misir, 2018; Hussain, 2018). The use of instructional media should be a concern for teachers in every teaching and learning process, keep in mind by using instructional media it can improve the quality of teaching and learning activities, increase interest in learning and digitalization the forms of educational materials delivery (Sudjana \& Rivai, 2011; Erdoğan \& Dede, 2015; Han \& Niu, 2019).

Computers were synonymous with audiovisual media and multimedia, which had an advantages over print media (Balkan Kiyici, 2018). Using technology in education, especially computer-based learning, could help teachers achieve learning goals and improve student learning outcomes (Ghavifekr et al., 2014). Using educational media in the learning process also could help students improve comprehension, provide interesting data, and facilitate deduction of information (Tania \& Fadiawati, 2015). The function of media in the learning process is not only a means of assisting teachers but the media also plays a role in conveying the information or data that students need (Hidayati \& Wuryandari, 2012).

Therefore, teachers must have the intention and need to learn how to use instructional media to effectively achieve learning goals in the teaching and learning process (Nazir et al., 2012). Using instructional media that was integrated with the use of information technology in the learning process can help students develop the competencies to compete in the digital age as it is today, where information technology can help students to develop skills and increase motivation and expand knowledge independently without being limited in space and time (Ghavifekr et al., 2014). This study aims to obtain information about analyzing the needs of educational media development according to the needs of students and technological development, and the scope of this research will cover the use of educational media used during the learning process for craft and entrepreneurship, as well as how students think about learning multimedia as one type of instrucitonal media that apply in crat and entrepreneurship's learning process.

\section{Method}

The research method used is descriptive research, with a quantitative approach (Sugiyono, 2012). The data collection technique used a questionnaire with a rating scale based on the Likert scale (1-5) distributed on the sample, namely XI Science 1 with a total of 26 students and XI Sicence 2 with a total of 29 students, the whole sample becomes 55 students of SMA N 1 Susukan (purposive sample). The data obtained was analyzed quantitatively using the statistics to know the value of the means and percentages with regard to the use of instructional media, facilities in schools, as well as students' need on developing instructional multimedia in craft and entrepreneurship's subject.

\section{Results and Discussions}

As mentioned in the previous section, data collection technology uses a Likert scale questionnaire (1-5) in order for students 'answers to the distributed questionnaire to be calculated and interpreted as follows. 
Table 1. Mean Value and Questionnaire Interpretation

\begin{tabular}{ccc}
\hline Mean Score & Level & Interpretation \\
\hline $\mathbf{1 . 0 0}-\mathbf{1 . 8 0}$ & Very Low & Strongly Disagree/Very Inappropriate (STS) \\
$\mathbf{1 . 8 1}-\mathbf{2 . 6 0}$ & Low & Disagree/Inappropriate (TS) \\
$\mathbf{2 . 6 1}-\mathbf{3 . 4 0}$ & Medium & Neutral (N) \\
$\mathbf{3 . 4 1}-\mathbf{4 . 2 0}$ & High & Agree/Suitable (S) \\
$\mathbf{4 . 2 1}-\mathbf{5 . 0 0}$ & Very High & Strongly Agree/Very Suitable (SS) \\
\hline
\end{tabular}

Source: Hadiyanto, Amirul Mukminin, Makmur, Marzul Hidayat (2013)

This section will convey information from the results of the needs analysis questionnaire that was completed by the entire sample regarding students' opinions on developing a learning media model that has been integrated with technology. Data from the questionnaire analysis are presented in the following table (table 2).

Tabel 2. Results of Identification of Analysis Needs for Developing Learning Media

\begin{tabular}{|c|c|c|c|c|c|}
\hline No & Item & Mean & Std. & Level & Interpretation \\
\hline 1. & $\begin{array}{l}\text { The teacher uses the methods of learning, } \\
\text { lecturing and discussing }\end{array}$ & 4.04 & .543 & High & Agree / Suitable (S) \\
\hline 2 & $\begin{array}{l}\text { The teacher uses computer-based learning } \\
\text { media }\end{array}$ & 2.36 & 1.043 & Low & $\begin{array}{l}\text { Disagree / } \\
\text { Inappropriate (TS) }\end{array}$ \\
\hline 3. & $\begin{array}{l}\text { The quality of learning media used by } \\
\text { teachers }\end{array}$ & 3.38 & .914 & High & Agree / Suitable (S) \\
\hline 4. & $\begin{array}{l}\text { Students can understand and the } \\
\text { explanations conveyed by the teacher }\end{array}$ & 4.02 & .527 & High & Agree / Suitable (S) \\
\hline 5. & $\begin{array}{l}\text { The teacher often uses the type of module } \\
\text { learning media }\end{array}$ & 4.04 & .527 & High & Agree / Suitable (S) \\
\hline 6. & $\begin{array}{l}\text { The teacher has never used multimedia } \\
\text { learning }\end{array}$ & 2.80 & .951 & $\begin{array}{l}\text { Mediu } \\
\mathrm{m}\end{array}$ & Neutral (N) \\
\hline 7. & Students' ability to operate computers & 3.53 & .879 & High & Agree / Suitable (S) \\
\hline 8. & $\begin{array}{l}\text { Whether or not learning is done using } \\
\text { multimedia based on local capabilities in } \\
\text { craft and entrepreneurship topics }\end{array}$ & 4.22 & .629 & $\begin{array}{l}\text { Very } \\
\text { High }\end{array}$ & $\begin{array}{l}\text { Strongly Agree / Very } \\
\text { Suitable (SS) }\end{array}$ \\
\hline 9. & There is a computer lab in the school & 3.47 & .813 & High & Agree / Suitable (S) \\
\hline 10. & $\begin{array}{l}\text { The teacher uses the multimedia learning } \\
\text { program during the learning process }\end{array}$ & 2.91 & .888 & $\begin{array}{l}\text { Mediu } \\
\mathrm{m}\end{array}$ & Neutral (N) \\
\hline
\end{tabular}

Table 2. showed the results of determining the questionnaire that students have filled out regarding many aspects of needs analysis in the context of developing learning media in the form of multimedia. Student responses to the need to develop learning media contain a variety of intermediate values, and the average or overall average obtained roughly is included in the "High" level.

As in item No. 1,3,4,5,7,9, students gave an answers to each component with the means values that are included in the "high" level, in item No. 2 the value of the means is listed in the "low" level, this as required by students. For items 6 and 10 included in the "medium" level, and those listed in the "very high" level are item No. 8. 


\section{The use of media in learning craftsmanship and entrepreneurship}

Based on the table. The overall results of the needs analysis questionnaire were identified, and this section will discuss the use of instructional media that teachers used in craft and entrepreneurship topics. Items indicating the media usage that the teacher uses during the learning process are transferred in items 5, 6 and 10 .

Table 3. Student Responses to the Use of Instructional Media

\begin{tabular}{clcccc}
\hline No & \multicolumn{1}{c}{ Item } & Mean & Std. & Interpretation \\
\hline 5. & $\begin{array}{l}\text { The teacher often uses the type of module } \\
\text { learning media }\end{array}$ & 4.04 & .527 & Agree / Suitable (S) \\
\hline 6. & $\begin{array}{l}\text { The teacher has never used multimedia } \\
\text { learning }\end{array}$ & 2.80 & .951 & Neutral (N) \\
\hline 10. & $\begin{array}{l}\text { The teacher uses the multimedia learning } \\
\text { program during the learning process }\end{array}$ & 2.91 & .888 & Neutral (N) \\
\hline
\end{tabular}

Table 3. showed that students have provided a high response to the teacher's learning methods, which is the unit provided by the government (mean $=4.04$ ), with details that up to $63.6 \%$ of students "agreed" that in the learning process teachers mostly use supplied units By the government. The modules include one type of material-containing learning media, which is systematically designed for efficiency and the unit type is divided into electronic and printed modules (Puspitasari, 2019). But the facts in this study are that the teacher is still using the printed version of the unit, so students cannot bring the unit to study independently.

Additionally, based on the table known that during learning activities, teachers still use multimedia as a learning tool, although not often, information is obtained through interviews with teachers, that media The multiple commonly used by teachers were powerpoint presentation modes. It can be seen on Item No. 6 , among the answers of students who agree and disagree, is still nearly balanced, although the majority of students say "agree" (around 50.9\% students) that the teacher has used multimedia learning.

\section{Learning support facilities in schools}

Computer labs with appropriate computer units are an important component of applying information technology in schools, whether in school management systems or in learning management. It is expected that the use of information technology in the form of computers and their use in the learning process will be integrated due to the many positive effects of the use of computers in the learning process in school. As revealed by Erdoğan \& Dede (2015) they found that the scores in science and technology in the experimental group were much higher than the control group, these results indicate that there are benefits to the learning process by using computers rather than using media and methods that tends to be conventional.

Given the importance of supporting facilities such as computers, the next aspect of need analysis is learning support facilities in schools in the context of developing and implementing learning media that utilize computers. The item that shows the related aspect is item number 9 .

Table 4. Student Responses to Learning Facilities at Schools

\begin{tabular}{ccccc}
\hline No Item & \multicolumn{1}{c}{ Item } & Mean & Std. & Interpretation \\
\hline 9. & There is a computer lab in the school & 3.47 & .813 & Agree / Suitable (S) \\
\hline
\end{tabular}

Based on table, students were known to provide a high response to support facilities in the learning process, especially issues related to the application of information technology (IT) in teaching and learning activities with means score $=3.47$, with the details of $52.7 \%$ of students said "agree" Schools had computer labs that can be used for the learning process. The results of student responses were enhanced by interviews with subject teachers, as the school already has about 60 computer units in two classes (laboratories), although the teacher acknowledges that she rarely used a computer lab for the learning process. 


\section{Perception and Opportunities of Multimedia as a Way to Learn Crafts and Entrepreneurship Topics}

This section will describe the results of the analysis of the aspects of perception and opportunities of the application of multimedia to the learning process. Items showing related to these aspects are items number 7 and 8 .

Table 5. Results of Perception Regarding Multimedia Opportunities for Learning

\begin{tabular}{clcccc}
\hline No & \multicolumn{1}{c}{ Item } & Mean & Std. & Level & Interpretation \\
\hline 7. & Students' ability to operate computers & 3.53 & .879 & High & Agree / Suitable (S) \\
\hline 8. & $\begin{array}{l}\text { Whether or not learning is done using } \\
\text { multimedia based on local capabilities in } \\
\text { craft and entrepreneurship topics }\end{array}$ & 4.22 & .629 & Very & $\begin{array}{c}\text { Strongly Agree / } \\
\text { Very Suitable (SS) }\end{array}$ \\
\hline
\end{tabular}

Based on the results of analyzing concepts and opportunities for multimedia in the learning process, it appeared that students provide positive answers that say 'agree' on the development and use of multimedia in craft and entrepreneurship topics, these results were shown by the average response of students who fall into a level that is 'strongly agree' with the means score $=4.22$. The opportunities for multimedia to use as creations for the learning process are very large given the average height of students with the ability to operate computers (mean score $=3.53$ ) then it appearead that students in general had the ability to operate computers. The percentage data for student responses to multimedia development will be illustrated in the following illustration.

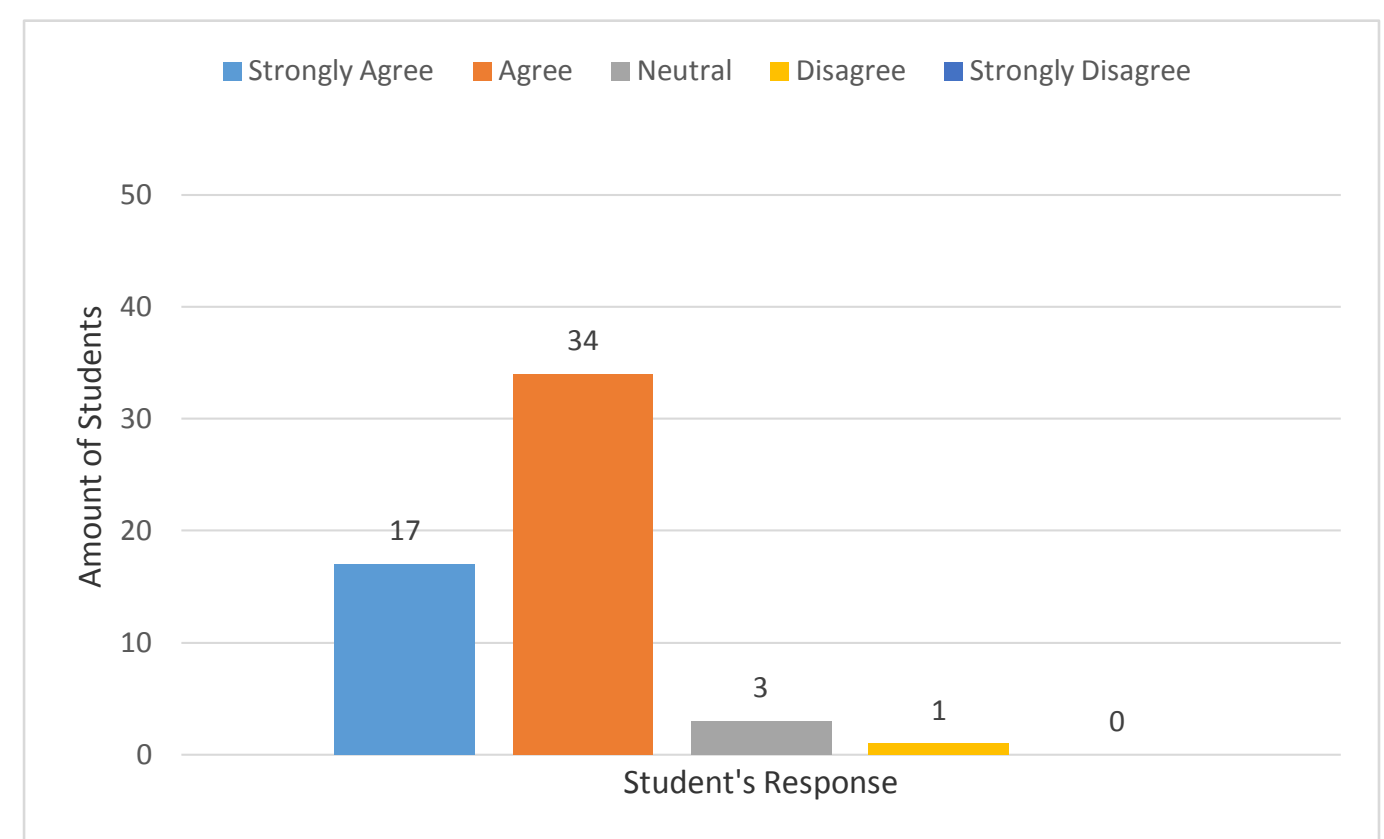

Figure 1. Student response to development opportunities and utilization of learning multimedia

Based on these graphs, it is known that student responses were very receptive to the development and use of instructional multimedia with details of 17 students (30.7\%) stating 'strongly agree' and followed by 34 students $(61.8 \%)$ stating 'agreeing' to develop a product multimedia learning for learning activities on the subject of craftsmanship and entrepreneurship.

The presence of interactive multimedia in the learning process begins with the development of information technology which requires students to have 21st century skills, one of which is being able to operate technology or other things that are digital (Sahidillah \& Miftahurrisqi, 2019; Moreira et al., 2019), it makes that utilization of computers become one of the solutions for learning in the current era. The material in subjects delivered through interactive multimedia has more advantages if it is only delivered orally, this is due to the characteristics of interactive multimedia, which is dynamic, interactive, and independent for students to learn (Guo \& Jia, 2016; Septian, 2019), can receive the information in the form of audiovisual, text, images and others such as multimedia arrangements (Kareem, 2018; Putra, 2018). 
Some relevant research states that the use of multimedia learning can affect student academic achievement (Budiastuti et al., 2018; Ponimin \& Suryani, 2019), attract students' attention, facilitate students in mastering the concepts of the material presented, create an active and capable learning atmosphere being a medium for individual student learning (Suyanto, 2003; Suyitno, 2016; Lindner et al., 2017). Another thing that supports the development of multimedia learning potential for craft and entrepreneurship subjects is that the teacher is familiar with the use of computers, even though the media used are only limited to powerpoints for presentations.

Therefore it needed innovative instructional media that can motivate students to learn and can explain highly complex educational materials. On the other hand, the teacher should able to combine appropriate and relevant learning methods and media, it will make the students easily understand the materials. Multimedia learning as mentioned above can be used as an innovative media learning solution that appears to be able to meet the needs of the learning media according to changing times.

\section{Conclusions}

Innovation in the learning process becomes fundamental to be able to create a conducive and effective learning atmosphere. One form of innovation to create a conducive learning atmosphere is through the development and utilization of computer-based learning media, namely multimedia learning. The development of information and communication technology that is increasingly fast requires teachers to always be able to utilize learning media in the learning process. The results of this study indicate: 1) Government-provided units control the use of media in the craft and entrepreneurship learning process, 2) Students have the ability to operate computers, 3) Teachers rarely use computer-based media such as strengths and videos of the process Learning Although facilities in schools are very supportive for developing instructional media such as computer-based learning, 4) Multimedia learning has an opportunity to overcome the media use restrictions that teachers can use in craft and entrepreneurship topics, and this is also supported by positive response from the students toward developing multimedia for learning process. Based on the research that had been done, teachers must be able to develop multimedia learning in craft and entrepreneurial topics and can be combined with curricula and learning methods that suit your needs. In addition, teachers were expected to be able to develop themselves through the activities by creating multimedia products for craft and entrepreneurship or other subjects.

\section{References}

Agustin, P. U. W., Wahyuni, S., \& Bachtiar, R. W. (2018). Pengembangan modul Fisika Berbasis Potensi Lokal "Batik Lumbung dan Tahu Tamanan" Untuk Siswa SMA di Kecamatan Tamanan Bondowoso (Materi Suhu Dan Kalor). Jurnal pembelajaran fisika, $7(1), 62$. https://doi.org/10.19184/jpf.v7i1.7226

Asmara, A. P. (2015). Pengembangan Media Pembelajaran Berbasis Audio Visual tentang Pembuatan Koloid. Jurnal Ilmiah Didaktika, 15(2), 156. https://doi.org/10.22373/jid.v15i2.578

Balkan Kiyici, F. (2018). Primary School Students' Perceptions Of Technology. Malaysian Online Journal of Educational Technology, 6(4), 53-66. https://doi.org/10.17220/mojet.2018.04.005

Bayne, S. (2015). What's the matter with 'technology-enhanced learning'? Learning, Media and Technology, 40(1), 5-20. https://doi.org/10.1080/17439884.2014.915851

Budiastuti, P., Khairuddin, M., \& Azman, M. N. . (2018). E-Instructional Multimedia in Basic Concepts of Electrical and Electronic Lessons. Jurnal Pendidikan Teknologi Dan Kejuruan, 24(2), 262-269. https://doi.org/10.21831/jptk.v24i2.18714

Daniel, D. B., \& Woody, W. D. (2013). E-textbooks at what cost? Performance and use of electronic v. print texts. Computers \& Education, 62, 18-23. https://doi.org/10.1016/j.compedu.2012.10.016

Erdoğ an, Y., \& Dede, D. (2015). Computer assisted project-based instruction: The effects on science achievement, computer achievement and portfolio assessment. International Journal of Instruction, 8(2), 177-188. https://doi.org/10.12973/iji.2015.8214a

Eteokleous, N. (2008). Evaluating computer technology integration in a centralized school system. Computers \& Education, 51(2), 669-686. https://doi.org/10.1016/j.compedu.2007.07.004

Fardila, V., Subekti, S., \& Setiawati, T. (2015). Manfaat Pembelajaran "Prakarya Dan Kewirausahaan" 
Dalam Penumbuhan Sikap Wirausaha Siswa Sman 1 Cimahi. Media Pendidikan, Gizi, Dan Kuliner, 4(2), 66-78. https://ejournal.upi.edu/index.php/Boga/article/view/8421

Feng, L., \& Sass, T. R. (2017). Teacher Quality and Teacher Mobility. Education Finance and Policy, 12(3), 396-418. https://doi.org/10.1162/EDFP_a_00214

Gan, B., Menkhoff, T., \& Smith, R. (2015). Enhancing students' learning process through interactive digital media: New opportunities for collaborative learning. Computers in Human Behavior, 51, 652663. https://doi.org/10.1016/j.chb.2014.12.048

Ghavifekr, S., Razak, A., Ghani, M., Ran, N., Meixi, Y., \& Tengyue, Z. (2014). ICT Integration in Education: Incorporation for Teaching \& Learning Improvement. Malaysian Online Journal of Educational Technology, 2(2), 24-45.

Guo, T., \& Jia, Q. (2016). Research on the impact of multimedia computerbased english teaching in high school. International Journal of Emerging Technologies in Learning, 11(8), 33-39. https://doi.org/10.3991/ijet.v11i08.6042

Hadiyanto, Amirul Mukminin, Makmur, Marzul Hidayat, F. (2013). Teaching in a Digital Era: English Lecturers' Readiness toward the Internet Use in Teaching and Learning at Selected Higher Education Institutions in Indonesia. Asia-Pacific Collaborative Education Journal, 9(2), 113-124.

Halili, S. H. (2019). Technological Advancements in Education 4.0. The Online Journal of Distance Education and E-Learning, 7(1), 63-69.

Han, M., \& Niu, S. (2019). Effect of computer multimedia assisted word annotation on incidental vocabulary acquisition of English reading. International Journal of Emerging Technologies in Learning, 14(13), 21-32. https://doi.org/10.3991/ijet.v14i13.10705

Hanafy, M. S. (2014). Konsep Belajar dan Pembelajaran. Lentera Pendidikan: Jurnal Ilmu Tarbiyah Dan Keguruan, 17(1), 66-79. https://doi.org/10.24252/1p.2014v17n1a5

Hidayati, N., \& Wuryandari, A. I. (2012). Media Design for Learning Indonesian in Junior High School Level. Procedia - Social and Behavioral Sciences, 67, 490-499. https://doi.org/10.1016/j.sbspro.2012.11.354

Huang, R. (2018). Development of a Cloud-based Network Teaching Platform. International Journal of Emerging Technologies in Learning (IJET), 13(04), 176. https://doi.org/10.3991/ijet.v13i04.8258

Hussain, Z. (2018). the Effects of Ict-Based Learning on Students' Vocabulary Mastery in Junior High Schools in Bandung. International Journal of Education, 10(2), 149-156. https://doi.org/10.17509/ije.v10i2.7592

Hussin, A. A. (2018). Education 4.0 Made Simple: Ideas For Teaching. International Journal of Education and Literacy Studies, 6(3), 92-98. https://doi.org/10.7575/aiac.ijels.v.6n.3p.92

Jones, S. J. (2017). Technology in the Montessori Classroom: Teachers' Beliefs and Technology Use. Journal of Montessori Research, 3(1), 16. https://doi.org/10.17161/jomr.v3i1.6458

Kali, Y., McKenney, S., \& Sagy, O. (2015). Teachers as designers of technology enhanced learning. Instructional Science, 43(2), 173-179. https://doi.org/10.1007/s11251-014-9343-4

Kapi Kahbi, A. Y., Osman, N., Ramli, R. Z., \& Taib, J. M. (2017). Multimedia education tools for effective teaching and learning. Journal of Telecommunication, Electronic and Computer Engineering, $9(2-$ 8), 143-146. http://journal.utem.edu.my/index.php/jtec/article/view/2645

Kareem, A. A. (2018). The Use of Multimedia in Teaching Biology and Its Impact on Students ' Learning Outcomes. The Eurasia Proceedings of Educational \& Social Sciences, 9(1), 157-165. https://dergipark.org.tr/download/article-file/531778

Lindner, M. A., Eitel, A., Strobel, B., \& Köller, O. (2017). Identifying processes underlying the multimedia effect in testing: An eye-movement analysis. Learning and Instruction, 47, 91-102. https://doi.org/10.1016/j.learninstruc.2016.10.007

Maresch, D., Harms, R., Kailer, N., \& Wimmer-Wurm, B. (2016). The impact of entrepreneurship education on the entrepreneurial intention of students in science and engineering versus business studies university programs. Technological Forecasting and Social Change, 104, 172-179. https://doi.org/10.1016/j.techfore.2015.11.006

Misir, H. (2018). Digital Literacies and Interactive Multimedia-. International Online Journal of Education and Teaching (IOJET), 5, 514-523. http://iojet.org/index.php/IOJET/article/view/178/250

Moreira, M. A., Rivero, V. M. H., \& Sosa Alonso, J. J. (2019). Leadership and school integration of ICT. Teachers perceptions in Spain. Education and Information Technologies, 24(1), 549-565. https://doi.org/10.1007/s10639-018-9789-0

Nazir, M., Rizvi, A., \& Pujeri, R. (2012). Skill development in multimedia based learning environment in higher education: An operational model. International Journal of Information, 2(11), 820-828. 
Nicolaou, C., Matsiola, M., \& Kalliris, G. (2019). Technology-Enhanced Learning and Teaching Methodologies through Audiovisual Media. Education Sciences, 9(3), 196. https://doi.org/10.3390/educsci9030196

Notanubun, Z. (2019). Pengembangan Kompetensi Profesionalisme Guru di Era Digital (Abad 21). Jurnal Bimbingan Dan Konseling Terapan, 3(2), 54. https://doi.org/10.30598/jbkt.v3i2.1058

Ponimin, P., \& Suryani, H. (2019). Instructional Media and English: Using Macromedia Flash to Teach EFL Writing. Edukasi: Jurnal Pendidikan Dan Pengajaran, 6(2), 311-319. https://doi.org/10.19109/ejpp.v6i2.3971

Pramita, M., Mulyati, S., \& Susanto, H. (2016). Implementasi Desain Pembelajaran pada Kurikulum 2013 dengan Pendekatan Kontekstual. Jurnal Pendidikan, 1(3), 289-296. https://doi.org/10.17977/jp.v1i3.6150

Puspitasari, A. D. (2019). Penerapan Media Pembelajaran Fisika Menggunakan Modul Cetak dan Modul Elektronik pada Siswa SMA. Jurnal Pendidikan Fisika, 7(1), 17-25. https://doi.org/https://doi.org/10.24252/jpf.v7i1.7155

Putra, L. (2018). Pengembangan Multimedia Pembelajaran Interaktif Pengenalan Pariwisata Lokal Berbasis Macromedia Flash untuk Siswa Sekolah Dasar Yogyakarta. Jurnal JPSD (Jurnal Pendidikan Sekolah Dasar), 5(2). https://doi.org/10.12928/jpsd.v5i2.12583

Rusdin, N. M. (2018). Teachers' Readiness in Implementing 21st Century Learning. International Journal of Academic Research in Business and Social Sciences, 8(4), 1293-1306. https://doi.org/10.6007/IJARBSS/v8-i4/4270

Sahidillah, M. W., \& Miftahurrisqi, P. (2019). Whatsapp sebagai Media Literasi Digital Siswa. Jurnal VARIDIKA, 31(1), 52-577. https://doi.org/10.23917/varidika.v1i1.8904

Septian, D. (2019). Pengaruh Multimedia Interaktif Berbasis Learning Cycle Terhadap Hasil Belajar Siswa. Jurnal Pendidikan Fisika Dan Sains, 2(1), 6-16. http://journal.unucirebon.ac.id/index.php/jpfs\%0APengaruh

Sofyan, H., Anggereini, E., \& Saadiah, J. (2019). Development of E-Modules Based on Local Wisdom in Central Learning Model at Kindergartens in Jambi City. European Journal of Educational Research, 8(4), 1137-1143. https://doi.org/10.12973/eu-jer.8.4.1139

Suasana, G. K. I. G. A., Ekawati, N. W., Sudiana, I. K., \& Wardana, I. G. (2020). Dampak Pendidikan Kewirausahaan pada Entrepreneur Behavior Index ( EBI ) dan Intensi Berwirausaha. MATRIK: JURNAL MANAJEMEN, STRATEGI BISNIS DAN KEWIRAUSAHAAN, 14(1), 31-42.

Sudjana. (2010). Penilaian Hasil Proses Belajar Mengajar. Rosdakarya.

Sudjana, N., \& Rivai, A. (2011). Media pengajaran. Sinar Baru Algesindo.

Sugiyono. (2012). Metode Penelitian Kuantitatif, Kualitatif dan R \& D.Bandung:Alfabeta. Metode Penelitian Kuantitatif, Kualitatif Dan $R \quad \& \quad$ D.Bandung:Alfabeta. https://doi.org/10.1017/CBO9781107415324.004

Sukiman. (2012). Pengembangan Media Pembelajaran. Pustaka Insan.

Sutrisno, V. L. P., \& Siswanto, B. T. (2016). Faktor-faktor yang mempengaruhi hasil belajar siswa pada pembelajaran praktik kelistrikan otomotif smk di kota yogyakarta. Jurnal Pendidikan Vokasi, 6(1), 111. https://doi.org/10.21831/jpv.v6i1.8118

Suyanto. (2003). Multimedia Alat untuk Meningkatkan Keunggulan Bersaing. Andi Offset.

Suyitno. (2016). Pengembangan multimedia interaktif pengukuran teknik untuk meningkatkan hasil belajar siswa SMK. Jurnal Pendidikan Teknologi Dan Kejuruan, 23(1), 101-109.

Tania, L., \& Fadiawati, N. (2015). The development of interactivee-book based chemistry representations referred to the curriculum of 2013. Jurnal Pendidikan IPA Indonesia, 4(2), 164-169. https://doi.org/10.15294/jpii.v4i2.4186

Taseman, \& Dahlan, A. M. (2018). Tantangan Pendidikan Menghadapi Era Revolusi Industri 4.0. Journal of Islamic Elementary Shcool (JIES), 3(2), 36-42.

Wanyama, T. (2017). Using industry 4.0 technologies to support teaching and learning. International Journal of Engineering Education, 33(2), 693-702.

Widodo, J., Huda, C., Dirgatama, A., \& Wirawan, A. W. (2020). Feasibility test application of information systems in the media as a learning in vocational school. 14(1), $28-33$. https://doi.org/10.11591/edulearn.v14i1.14674

Wihartanti, L. V., \& Wibawa, R. P. (2017). Development of e-Learning Microsoft Sway as Innovation of Local Culture-Based Learning Media. Dinamika Pendidikan, 12(1), 53-60. 
https://doi.org/10.15294/dp.v12i1.10582

Winardi, J. (2003). Entrepreneur dan Entrepreneurship. Prenada Media.

Yildirim, H. I., \& Sensoy, O. (2018). The Effect of Science Teaching Enriched With Technological Applications on the Science Achievements of 7th Grade Students. Journal of Education and Training Studies, 6(9), 53. https://doi.org/10.11114/jets.v6i9.3363

Yue, N. (2017). Computer multimedia assisted English vocabulary teaching courseware. International Journal of Emerging Technologies in Learning, 12(12), 67-78. https://doi.org/10.3991/ijet.v12.i12.7955

Yuzarion, Y. (2017). Faktor Yang Mempengaruhi Prestasi Belajar Peserta Didik. Ilmu Pendidikan: Jurnal Kajian Teori Dan Praktik Kependidikan. https://doi.org/10.17977/um027v2i12017p107

Zhang, Y. (2018). Development of WebGL-based Virtual Teaching Platform for Mold Design. International Journal of Emerging Technologies in Learning (IJET), 13(06), 16. https://doi.org/10.3991/ijet.v13i06.8581 